\title{
Hvem styrer fængslerne og fangehåndteringen i Danmark?
}

\author{
Stillingen som direktør for fængselsvæsenet/ \\ kriminalforsorgen gennem 111 år $^{1}$
}

Af Peter Fransen, seniorforsker, Rigsarkivet København

\begin{abstract}
This article analyses how the directors of the Prison and Probation Service have dealt with the treatment of convicted prisoners over the past 111 years. What opinions have they expressed on the issues? What values have they wanted to promote? What influence have they had on the system's development? These top officials have had to deal with a changing political reality. Furthermore, their position has become increasingly administrative in recent decades with less emphasis placed on their professional perspectives concerning the treatment of convicted prisoners.

\section{Keywords}

Prisoner treatment, Directors of the Danish Prison and Probation Service, Public Administration Fangebehandling, Direktører for direktoratet for kriminalforsorgen, offentligadministration
\end{abstract}

\section{Indledning}

Det har ikke hidtil været almindeligt her i Landet, at Embedsmænd i ledende Stillinger afgiver »Programerklæringer« om deres »/deer« og »Tro«, at de forud gør Rede for, hvad de vil udføre. Det gælder for saadanne Embedsmænd om at gennemføre de Tanker, de har om de under deres Administration hørende Forhold. ${ }^{2}$

1. Title in English: Who oversees prisons and prison management in Denmark? 111 years of changes in the responsibilities of the Director of the Danish Prison and Probation Service.

2. Brev fra direktøren for fængselsvæsenet Thorkil Fussing til justitsminister C. Th. Zahle dateret den 17. august 1919. Anledningen til brevet var Nyborg-sagen, hvor brodne kar inden for personalet på straffeanstalten i Nyborg voldte problemer. Den konservative folketingspolitiker Arnold Fraenkel benyttede denne sag til voldsomt at kritisere Fussing.

Fussing gav efterfølgende en redegørelse for de idéer, han ønskede af gennemføre i fængselsvæsenet samt de resultater, han mente, der var nået. Justitsministeren støt- 
I 2014 fik direktoratet for kriminalforsorgen ophævet sin ministerumiddelbarhed - også i spørgsmålet om fangehåndtering. Dermed sluttede en 104-årig tilstand, uden at det blev bemærket i offentligheden. I artiklen ses der på, hvorledes de indtil nu 12 udnævnte direktører har ageret i forhold til opgaven med fangebehandlingen. Hvorledes har de ytret sig om spørgsmålet, hvilke værdier ønskede de at fremme, og kom de til at præge udviklingen? I begrænset omfang gøres det med referencer til ændringer og trends i den fængselspolitiske virkelighed. Der sættes fokus på, hvad der var nyt i deres embedsperiode, og spørgsmålet stilles, om direktørerne havde mulighed for at realisere de ønsker, som de formulerede for fangebehandlingen. Fokus vil være, hvad de enkelte stod for og udrettede. Som topembedsmænd har de alle skullet agere i et politisk sensibelt system. Artiklen ser på direktørernes vanskelige balancegang mellem at være ministerens administrative tjener og deres egne faglige ambitioner om at udvikle fangebehandlingen. Det er med andre ord stillingen og indehavernes engagement i spørgsmålet om fangebehandlingen, der er omdrejningspunktet i artiklen. Herigennem spejles udviklingen i fangebehandlingen over en 111-årig periode set ud fra den indflydelsesrige administrative toppost. Set i forhold til selve den strukturelle historiske udvikling inden for fængselsvæsenet giver det en skævvridning, man skal være sig bevidst.

Forskningsmæssigt er der hentet inspiration fra prosopografien, hvor det ikke er et detaljeret portræt af et enkelt individs liv og virke, der er i centrum, men hvor der derimod fokuseres på en gruppe af individer (Keats-Rohan 2003, s. 1-3). Den prosopografiske metode kan defineres som en unders $\varnothing$ gelsesmetode, der i gennem indsamling, analyse og systematisering af data vedrørende en ud fra et væsentligt fælles kriterium nøjagtig defineret gruppe personer, søger at nå frem til gruppens karakteristika (Stone 1971, s. 46 og Ilsø 1985 s. 111). Den til tider ophedede diskussion om prosopografien og ikke mindst biografigenrens videnskabelige berettigelse er ikke artiklens tema, men skal akkrediteres, da den har stimuleret til at afprøve formen. ${ }^{3}$ I herværende artikel er fællesnævneren, at de biograferede har været direktører for fængselsvæsenet/kriminalforsorgen, og de data, der er blevet indsamlet og vurderet, er deres udmeldinger om fangebehandlingen.

Artiklen er ikke en udtømmende prosopografisk analyse, men der stilles skarpt på direktørernes ytringer angående fangebehandlingen.

tede uden forbehold Fussing (Direktoratet for fængselsvæsenet journalsag 1002/1916, Rigsarkivet. Se også Fransen 2015, s. 13-19).

3. Se f.eks. Birgitte Possings bog Ind i biografien fra 2015 og Kristoffer Schmidts kritiske debatanmeldelser Biografi, akribi og lidt om helte og heltinder 2015. I Jo Rune Ugulen Kristiansens paper Prosopografi og historie fra 2005 konkluderes:"Prosopografi vert dermed, eller bør i det minste vera ei naturleg grein innanfor den metodologiske pluralismen i historiefaget. 


\section{Thorkil Fussing - den første direktør for fængselsvæsenet i Danmark 1910-1927}

Direktoratet blev oprettet som en direkte følge af den voldsomme kritik, der omkring år 1900 fremkom imod den daværende ledelse af fængselsvæsenet. Penneføreren var Thorkil Fussing, som i 1903 skarpt angreb den daværende overinspektion for fængselsvæsenet. Kritikken gik på nepotisme, magtmisbrug og dårlig forvaltning. Fussings kritik blev hørt. Politisk ønskede både Venstre og Det Radikale Venstre (fra 1905) et opgør med de embedsmænd, som Højre havde udnævnt. Direktoratet blev etableret i 1910, og som direktoratets første direktør udnævntes den tidligere fængselsadministrations fremmeste kritiker - Thorkil Fussing. Ikke alle var dog lige begejstrede for udnævnelsen. For eksempel anførte Stener Frederik Grundtvig, fængselsinspektør i Vestre Fængsel 1895-1910 og hovedredaktør af Nordisk Tidsskrift for Fængselsvæsen og praktisk Strafferet frem til 1911, at stillingen var skruet således sammen, at ingen kvalificerede personer kunne søge jobbet, og blandt de ansøgere, der trods alt var, valgte justitsministeriet den ringeste (Grundtvig, s. 68 og 72). Det lykkedes ikke desto mindre Fussing i sin embedstid administrativt at reformere ledelsen af fængselsvæsenet og aktivt præge debatten om fangehåndteringen.

Direktøren skulle stå for ledelsen af og tilsynet med landets fængselsvæsen samt udføre departementale opgaver vedrørende udståelse, eftergivelse og formildelse af straf. Mens den tidligere overinspektør for fængselsvæsenet havde været deltidsansat, udviklede direktoratet for fængselsvæsenet sig til et egentligt departementalt administrativt system.

Mangel på fængselspladser og frem for alt anstændige fysiske rammer for afsoningen optog Fussing såvel som mange af hans efterfølgere. Fussing arvede planerne om opførelsen af landets tredje store straffeanstalt (efter Horsens i 1853 og Vridsløselille i 1859), men ham kom til kraftigt at præge den afsluttede planlægning. Ved ibrugtagningen af Statsfængslet i Nyborg i 1913 fik man et klart indtryk af, hvilke ambitioner Fussing havde for fangebehandlingen. Der skulle skabes et differentieret system af anstalter, så ældre og yngre fanger ikke skulle afsone i samme anstalter, og han så gerne, at der i fremtiden blev oprettet egentlige særfængsler. Hvad angik fangebehandlingen var 1800tals tankegangen om at resocialisere fangerne ved, at de skulle vende blikket indad, delvis forladt (Fransen 2013, s. 29). Ideologien var stadig at opdrage, men midlerne var ikke længere entydigt at satse på den kristne vækkelse af fangerne. Den »nye religion« kom til at hedde arbejde og rationalitet. Ikke at arbejde var ukendt i fængslerne før 1913, men vægtningen og organiseringen blev nu en ganske anden. Forenklet sagt skulle fangerne nu ikke længere frelses gennem troen, men gennem arbejde. Set, i det lys kan det ikke overraske, at Fussing også var fortaler for at begrænse cellearbejde til fordel for fællesarbejde. Modstanderne af isolationsfængselsideologien havde en markant allieret i fængselsdirektøren. Fussing anførte, at streng og langvarig 
isolation virkede uheldig, og det blev ikke blot ved snakken - i anordningen for Statsfængslet i Nyborg fra 1913 finder vi det første beskedne brud med det klassiske isolationssystem (Fussing 1921, side 21). Ved Fussings død i 1930 fremhævede hans efterfølger Kampmann, at det lykkedes Fussing at overføre de principper, som blev fulgt i de amerikanske og engelske ungdomsfængsler (Reformatorys og Borstal institutioner) i så stor udstrækning, som det lod sig gøre inden for den gældende straffelov (Kampmann 1931, s. 7). Fussing forbedrede fangernes mulighed for friluftsarbejde, der blev udfærdiget nye bespisningsreglementer, og i Nyborg blev der indført egentlig undervisning og de første spæde forsøg på at få knyttet forsorgsarbejdet til fængslerne. Der var med andre ord et skifte på vej (Fransen 2013 s. 56, 72-78). Fussing var en progressiv chef for et fængselsvæsen, der havde sine rødder i miden af 1800-tallet, men den gældende straffelov fra 1866 satte begrænsninger for mere grundlæggende reformer. En ny straffelov havde allerede længe været under opsejling. Siden 1905 havde flere kommissioner arbejdet intensivt med opgaven, men først i 1924 kunne den socialdemokratiske justitsminister K.K. Steincke fremsætte forslaget om en ny straffelov. Nu på baggrund af den seneste Straffelovskommissions betænkning fra 1923, heri indgik som bilag Fussings Bemærkninger om Frihedsstraffe og med Frihedsberøvelse forbundne Sikkerhedsforanstaltninger fra 1921. Selve Steinckes fremlæggelsestale blev nøje afstemt med Fussing, kontorchef L.H. Hvidt fra justitsministeriet samt departementschef F. Schrøder. Ønsket var en yderligere specialisering blandt de eksisterende fængsler, og anstaltssystemet skulle suppleres med ungdomsfængsel, sikkerhedsforvaring, arbejdshus m.m. ${ }^{4}$

Der skulle dog forløbe 10 år, inden en ny straffelov kunne træde i kraft. Hele tre forskellige justitsministre skulle få »fornøjelsen « af at fremlægge et sådant lovkompleks, inden den endelig blev vedtaget i 1930 med ikrafttrædelse 1. januar 1933 (Fransen 2010, s. 54-55). Fussing kom således til at sidde helt tæt på det lovforberedende arbejde, indtil han i 1925 - som 51 årig - måtte søge sygeorlov. Han døde i 1930.

\section{Direktører præget af ånden i Straffeloven af 1930. Erik Kampmann 1927-1942 og Hans Tetens 1943-1965}

Som Fussings efterfølger faldt det i Erik Kampmanns lod at tilpasse fængselsvæsenet til den nye straffelov. Loven indebar, at flere af de religiøst betingede straffe helt gled ud, og der var generelt tale om en lavere straframme end i 1866-straffeloven. Når de hårde straffe skulle afsones, skulle der tilbydes et differentieret fængselssystem, der opdelte fangerne efter deres alder og karakter og ikke udelukkende forbrydelsens grovhed. Kampmann havde arbejdet tæt sammen med Fussing, og han lå helt på linje med Fussing i de centrale fængselsspørgsmål. Kampmann havde tjent Fussing siden oprettel-

4. Rigsdagstidende. Forhandlinger i Folketinget 1924/25 sp. 2570-71. 
sen af direktoratet, henholdsvis som inspektør ved flere af landets fængsler og fra 1921 som chef for Direktoratets ekspeditionskontor. Under Fussings sygeorlov blev han konstitueret, og fra 1927 blev han udnævnt til direktør.

Kampmann var en for den tid klassisk topembedsmand - lærd med stor viden om både international og national strafafsoning. Hans gennemslagskraft over for politikerne og offentligheden må betegnes som mere behersket, men han så det næppe heller som sin primære opgave. Kræfterne blev brugt på at få implementeret de retningslinjer for fængselsvæsnet, der var udstukket i den vedtagne straffereform. Her skal der ikke gås i detaljer med reformen, men der skulle ifølge loven etableres følgende fængselsstrukturer:

- Statsfængsler til afsoning af fængselsstraf på over seks måneder

- Fængsel eller fængselsafdeling for psykopater

- Forvaringsanstalt for psykopater

- Ungdomsfængsel

- Anstalt eller anstaltsafdeling til afsoning af arbejdshus

- Anstalt eller anstaltsafdeling til sikkerhedsforvaring

Kampmann gav selv en detaljeret gennemgang af de nye anstaltsformer og den ændrede fangebehandling, som til dels var en følge heraf (Kampmann 1933A, s. 103-104, 117-125), men anførte at direktoratet først fuldstændigt kunne realisere straffelovens synspunkter, når nybygninger var tilvejebragt. Det skete delvis med opførelsen af Statens Arbejdshus Sønder Omme (1933) for ufarlige berigelseskriminelle med hang til uordentlig levevis, lediggang og drikkeri, ungdomsfængslet på Søbysøgaard (1933) og psykopatanstalten ved Herstedvester (1935), men generelt blev fængselsvæsenet henvist til at klare sig med de bestående bygninger og fængsler.

I modsætning til tidligere blev der nu indført meget vidtgående regler om særbehandling af lovovertrædere efter alder, karakter og psykisk tilstand. Direktoratet var hårdt spændt for med arbejdet med at etablere de nye fængsler og anstalter samt efterfølgende udarbejde anordninger, regler og instrukser for, hvorledes fangerne skulle behandles. Konstruktionen var således, at de kongelige anordninger indeholdt hovedreglerne og typisk var genstand for brede kommissionsbehandlinger, mens det mere detaljerede reglement var udarbejdet i henhold til bemyndigelse nævnt i anordningerne. Det betød, at de specificerede regler kunne ændres af fængselsvæsenet selv.

Kampmann selv fremhævede, at straffeloven rettede sin opmærksomhed mere på forbryderen end på forbrydelsen, og domstolen havde et meget frit spillerum for at kunne foretage strafudmåling efter hvert enkelt tilfældes karakter. Det stillede større krav end hidtil til fængselsvæsenet både på det menneskelige såvel som på det bygningsmæssige plan. Hvad enten det var en cellefange eller fællesfange, så havde disse skabelonmæssigt været håndteret efter reglementets bogstav, hvilket krævede forholdsvis få forudsætninger, set i forhold til en psykologisk og pædagogisk baseret individualiseret fange- 
behandling (Kampmann 1933B, s. 11). Det skulle blive en lang og hård kamp, som vel aldrig blev vundet.

Direktoratet fik også en helt ny opgave i forbindelse med oprettelsen af fængselsnævnet. Nævnet skulle træffe afgørelse om løsladelse af fanger, der afsonede delvist tidsubestemte straffe, altså ungdomsfængsel, arbejdshus og sikkerhedsforvaring. Det bestod af en dommer som formand, direktøren for fængselsvæsenet, en psykiater samt repræsentanter fra forsorgsarbejdet. De delvist tidsubestemte straffe blev i de første årtier efter den nye straffelovs eksistens anset for meget progressive, mens det især var kritikken af disse, der fra 1960'erne kaldte på en ny reform. Signaler som Kampmanns efterfølger ikke opfangede. Kampmann døde i embede i 1942 og blev efterfulgt af Hans Tetens - endnu en person, der allerede havde dyb indsigt i direktoratets arbejde, hvor han havde virket siden 1925. Han var på alle områder det oplagte og sikre valg som Kampmanns efterfølger.

Tetens undgik efter befrielsen 5. maj 1945 ikke kritik for sin rolle under samarbejdspolitikken, men han klarede frisag og kom til at stå med det overordnede ansvar for de vanskeligheder, som retsopgøret afstedkom. De såkaldte landssvigere var så talrige og udgjorde et helt nyt fangeklientel, som kaldte på nye afsoningsformer. Næsten umærkeligt skete der en glidning fra specifikt at være et spørgsmål om, hvorledes landssvigerne skulle tackles i de danske fængsler til at formulere tanker om, hvorledes alle indsatte i fængslerne skulle behandles. I 1945 havde modstandsbevægelsen gennem »Frit Danmark« afgivet en betænkning Om Principperne for Fuldbyrdelse af Frihedsstraf for forræderi og anden landsskadelig virksomhed (Betænkning 1945). Fængselsvæsenet var rigt repræsenteret i udvalget, men Tetens var ikke iblandt. Arbejdet blev videreført i det udvalg, som justitsministeriet nedsatte i februar 1946 under ledelse af Hans Tetens, og som afgav en foreløbig betænkning i 1946. Denne betænkning resulterede i den kongelige anordning af 10. maj 1947 angående fuldbyrdelse af fængselsstraf. Flere af de tanker, der kom frem under udvalgsarbejdet, må siges at være ganske revolutionerende. Straffuldbyrdelsen skulle bidrage til af fremme muligheden for, at fangerne bedre kunne integreres i samfundet efter afsoningen. Det var måske ikke så nyt, derimod var det nyt, at det blev pointeret, at frihedsberøvelsen var straf nok i sig selv (Foreløbig betænkning 1946, s. 8). Nok havde Fussing tilbage i 1924 luftet de samme tanker i et interview, hvor han udtalte, at selve fængselsopholdet kunne man gerne gøre humant uden fare for, at det skulle blive uden betydning. Frihedstrangen gjorde, at indespærringen var en tilstrækkelig hård straf (Nationaltidende 2. marts 1924), men på daværende tidspunkt vandt det ikke gehør. I 1946 var tiden moden til, at normaliseringstanken kunne holde sit indtog. Fængslet skulle ikke påføre andre lidelser udover selve frihedsberøvelsen. I sin logiske konsekvens måtte dette indebære en normalisering af afsoningen, så fangernes liv og rettigheder mest muligt kunne ligne livet i det omgivne samfund. Tankevækkende er det, at da fængslevæsenet i Nordisk Tidsskrift for Strafferet i 1947 præsenterede både de fængselsmæssige greb 
over for landssvigerne og selve udvalgsbetænkningen, var det Tetens, der tog sig af landssvigerne, mens det var den unge Carl Aude-Hansen, der berettede om den - for eftertiden - banebrydende betænkning. Tetens kunne i 1947 konstatere, at retsopgøret havde fået et betydeligt hurtigere forløb end oprindeligt antaget, hvilket gav sig udslag i en hurtigere løsladelse af de domfældte. Det var et forhold, han ikke bifaldt, da det fratog fængselsvæsenet muligheden for at opdrage landssvigerne både gennem arbejde og sindelagspåvirkning. Og han anførte, at lovgivning vedrørende strafferetslige spørgsmål var så ømfindtlig, at en usikker kurs kunne medføre forstyrrelser i befolkningens retsbevidsthed (Tetens 1947, s. 197). Tetens var ikke optaget af normaliseringstankegangen, men derimod af ønsket om at påvirke og opdrage de indsatte. Om end Tetens fremstår som positiv over for reformerne, så er det tydeligt, at initiativet ikke kom fra direktoratet, men at man reagerede på pres udefra.

I 1955 gjorde han status og fremhævede særligt fremkomsten af de åbne fængsler som betydningsfuld (Tetens 1956, s. 5). Etableringen fandt først sted under krigen og tog rigtig fart derefter. Efterhånden som landssvigerproblemet blev afviklet, blev ikke alle straffelejre afviklet, men overgik til husning af almindelige kriminelle fanger. Det, der i de efterfølgende år lå ham på sinde, var at få udbygget anstaltsstrukturen. Hvad angik fangebehandlingen lagde han vægt på oprettelsen af arbejdsværksteder, så fangerne efter løsladelsen kunne skaffe sig arbejde inden for den ekspanderende industrielle sektor. På papiret så det ganske fornuftigt ud, men visionært var det ikke. De erfaringer og resultater, der blev gjort i de åbne fængsler, synes ikke at være ledetråde for Tetens arbejde (Carl Aude-Hansen, s. 175-176, 1959).

Da direktoratet i 1960 kunne fejre sit 50 års jubilæum, befandt Tetens og direktoratet sig i smult vande, men det skulle hurtigt ændre sig. I pagt med de generelle anbefalinger fra statsadministrationen ønskede justitsministeriet at ophæve direktoratet for fængselsvæsenet og inkorporere opgaverne i ministeriet. Direktoratet blev først sent informeret om ministeriets planer og havde ikke haft lejlighed til at deltage i overvejelserne. Tetens betegnede forslaget som uantageligt. Den 20. januar 1965 meddelte ministeriet, at det oprindelige forslag var blevet forladt og henviste til den kraftige kritik, som Tetens havde fremsat. Ministeriet ville nu overveje situationen. De grundlæggende tanker var på ingen måde opgivet, og reelt betød det, at departementet afventede Tetens afgang. Tetens fik foretræde for ministeren i begyndelsen af februar, og han fik mulighed for mundtligt at redegøre for sine synspunkter. Desuden ønskede han at hindre, at direktoratet efter hans afgang fik konstitueret en mand udefra, da der ifølge ham fandtes velkvalificerede ansøgere inden for fængselsvæsenet. Tetens gik ikke til pressen, men en whistleblower i direktoratet lækkede oplysninger. ${ }^{5}$ Efterfølgende lod han sig pensionere. Tetens

5. Justitsministeriet journalsag 1968-010-17, Rigsarkivet og Direktoratet for Fængselsvæsenet 1. ekspeditionskontor 174/1964, Rigsarkivet. For en mere udførlig gennemgang se Fransen 2010, s. 78-85. 
fremstår som en temmelig anonym chef og i nogen grad i et modsætningsforhold til de mange nye og unge fængselsinspektører, som især i de åbne fængsler søgte at reformere fængselsvæsenet.

\section{Opgøret med behandlingsparadigmet og fokus på rettigheder til fangerne. Direktørerne Lars Norskov Nielsen 1967-1971 og H.H. Brydensholt 1971-1980}

Direktoratet fik konstitueret en person udefra, nemlig daværende dommer ved Østre landsret P.M. Christensen, og efterfølgende valgte justitsministeriet også at forbigå ansøgerne fra direktoratet. Valget faldt i 1967 på kontorchef i ministeriets lovafdeling Lars Nordskov Nielsen. Forud var gået en reel eksistenskamp, der mundede ud i, at fængselsdirektøren beholdt sit direkte referat til ministeren, altså sin departementale status, dog således at sager vedrørende budgettet og bevillinger skulle behandles gennem justitsministeriets departement. I Nordskov Nielsens embedsperiode revolutionerede han fængselsvæsenet og fik tilrettelagt reformerne således, at den straffelovsreform, der allerede var i spil, kom til at flugte med de overbevisninger, han repræsenterede. Troen på værdien og resultaterne af de delvist tidsubestemte sanktioner var fordampet, og Lars Nordskov Nielsen skulle hurtigt træde i karakter som særordningernes banemand. Han fremførte sin kritik af grundlaget for ungdomsfængslerne og satte fokus på særordningernes desillusion indadtil, en desillusion han ville veksle til et politisk opgør med ordningerne. ${ }^{6}$ Justitsministeriet havde i april 1967 anmodet Straffelovrådet om at se på hele straffelovens sanktionssystem. ${ }^{7}$ Nordskov Nielsen havde helt tilbage til oprettelsen af Straffelovrådet fungeret som sekretær for rådet, så han havde et indgående kendskab til arbejdet og personkredsen i rådsarbejdet. Der fulgte en lind strøm af betænkninger fra Straffelovrådet, som entydigt pegede i retning af afskaffelsen af særordningerne og grundlæggende revisioner af hele lovkomplekset. Opgøret med de delvist tidsubestemte straffe gik hånd i hånd med det holdningsskifte, der var på vej i fangehåndteringen og ønsket om af- og nedkriminalisering (Nilsson, s. 76-77).

Lars Nordskov Nielsen gentog gang på gang, at de indsattes retsstilling for ham var helt central i det reformarbejde, han allerede havde iværksat (Nordskov Nielsen 1969, s. 490). Han pustede nyt liv i bestræbelserne på at realisere de tanker, som betænkningen fra 1946 allerede have pointeret - at der ikke bør være andre restriktioner i de indsattes tilværelse end sådanne, som er

6. Justitsministeriet journalsag 1972-20002/181, Rigsarkivet, Strafferådet pakke 22, Rigsarkivet. Se også Fransen 2010 s. 88.

7. Straffelovrådet blev nedsat i 1960, og det påhviler rådet efter Justitsministeriets anmodning at afgive indstilling om strafferetlige lovgivningsspørgsmål og principielle spørgsmål vedrørende fastsættelsen af administrative bestemmelser af strafferetlig karakter og den praktiske gennemførelse af kriminalpolitiske foranstaltninger. 
nødvendige for gennemførelse af den frihedsberøvelse, som dommen går ud på. Det betød, at han iværksatte en systematisk gennemgang af alle regler i anordninger, reglementer m.v., der omhandlede de indsattes retsstilling med henblik på en analyse af, om de restriktioner, der var gældende, havde et rationelt formål, eller om de i hovedsagen var et traditionsprodukt. En rolig status quo-kadence under Tetens var afløst af en sand hvirvelvind. Nordskov Nielsen skabte grundlaget for, at rettigheds- og normaliseringstankegangen skulle fortrænge 1930-straffelovens behandlingstankegang - i hvert fald som den herskende overordnede ledelsesideologi. Der var ikke langt fra konstateringen af fangebehandlingens manglende succes til ønsket om at få færre fængslede ved at foretage en af- og nedkriminalisering.

I 1971 skiftede Nordskov Nielsen stillingen som direktør for fængselsvæsenet ud med stillingen som Folketingets Ombudsmand (1971-1981) og efterfølgende professor i forvaltningsret ved Københavns Universitet (1981-1994). Fra begge poster fortsatte med at følge fængselsvæsenet tæt, og hans aktive indflydelse på væsenet strakte sig langt ud over tiden som direktør. Grundtanken var, at retssystemet og det sociale system skulle vægre sig længst muligt ved at bringe den uhensigtsmæssige frihedsberøvelse i anvendelse. Når det endelig skete, havde det karakter af noget i retning af en afmagtshandling betinget af, at man ønskede at bringe aktiviteterne til ophør for en tid - selv om det ud fra en lidt mere langsigtet betragtning var en risikofyldt foranstaltning (Brydensholt 1975, s. 11-17). 1930-straffelovens behandlingsoptimisme var forladt. Fængselsformerne som Arbejdshus og Ungdomsfængsel blev afskaffet. Tiden var præget af af- og nedkriminalisering og tanker om alternativer til fængselsstraf. Helt i tråd med dette blev det danske fængselsvæsen i 1973 til den mere rummelige kriminalforsorg.

I 1971 havde H.H. Brydensholt efterfulgt Nordskov Nielsen på posten som direktør. Med sine 38 år var han den til dato yngste direktør for direktoratet. Han var dog ikke nogen novice inden for strafferetsplejen. Han havde været kontorchef i justitsministeriets lovkontor og sekretær i Straffelovrådet. Det var en bagage, der ikke var ulig den, som Nordskov Nielsen havde haft med, da han overtog posten. Nordskov Nielsen havde i sin embedsperiode fået placeret direktoratet stærkt i forhold til det politiske system og offentligheden generelt. Brydensholt var ligeledes en mand med visioner og med et blik for organisation og management. At være med til at stå fadder til den nye straffelov i 1973 gav både direktoratet og Brydensholt et stærkt udgangspunkt. Selvom meget af det, der blev søsat i 1970'erne, havde rødder i Nordskov-æraen, blev det Brydensholt, der skulle implementere disse tiltag og videreudvikle reformerne. Brydenholt har selv anført, at med disse reformer som ledetråd, var hans mål at nedbringe antallet af indespærrede og at gøre frihedsberøvelsen, altså fangernes adskillelse fra det almindelige samfund mindre absolut. Tidsånden i 1970'erne fandt han på mange måder gunstig for reformer. Når direktoratet for at holde kriminaliteten i ave foreslog nedkriminalisering og samarbejde uden for anstalterne, var der lydhørhed 
(Brydensholt 2010, s. 230). Efterfølgende steg presset igen på fængslerne på grund af store årgange, forringede konjunkturer og arbejdsløshed. Brydenholt holdt fast i den lagte linje, men der rejste sig et internt oprør imod ham fra inspektørernes side, ikke på grund af de fængselsideologiske synspunkter, men på grund en efter deres opfattelse for enevældig ledelsesstil. Hertil kom kritik af den økonomiske styring af direktoratet og en fejlvurdering af kapacitetsproblemerne i de store fængsler. I 1980 måtte han forlade sit embede. ${ }^{8}$

\section{Den humanistiske fængselsideologi udfordres. Tiden under direktørerne Frits Hellborn 1980-1985, Anders Troldborg 1986-1993, Christian Trønning 1993-1998, William Rentzmann 1998-2012}

Efter Brydensholts afgang ønskede ministeriet af finde en overgangsfigur til posten og et yderligere stækket direktorat. Valget faldt på den garvede Frits Hellborn, som siden 1944 havde haft sin gang i direktoratet og siden 1969 været chef for den administrative afdeling. Han måtte affinde sig med, at de linjer, som den magtfulde departementschef Niels Madsen havde trukket op for direktoratets virke, betød en yderligere ressortindskrænkning. I sit embede stod han umiddelbart under justitsministeren i afgørelse af konkrete sager samt ved udfærdigelse af generelle forskrifter vedrørende fuldbyrdelse af strafferetslige retsfølger. Undtaget var dog afgørelser og regler, der havde større principiel betydning eller kunne få større økonomiske konsekvenser. Også i alle øvrige sager stod direktøren i sit embede under justitsministeriets departement. Direktoratet lignede i stadig stigende grad en styrelse og i mindre grad et klassiskdirektorat. ${ }^{9}$

I perioden fra 1979-1982 steg den samlede idømte straf opgjort i måneder betydeligt. På grund af mangel på ledig kapacitet i fængslerne medførte stigningen, at ventekøen til afsoning blev endnu længere. For at afhjælpe denne situation blev kapaciteten i årene 1980-1982 udvidet fra ca. 3.450 pladser til 3.800. Justitsminister Ole Espersen understregede dog, at der ikke var tale om en ændring i den kriminalpolitiske linje, og arbejdet med begrænsning af frihedsstraffen ville fortsætte (Fransen 2010 s. 111-112). På trods af mange avisskriverier, som kritiserede Hellborns »blødsødne« holdning, holdt han fast ved den liberale kurs, som betød færrest mulige fanger og en afsoning, som skulle sikre, at fangerne slap så helskindede gennem fængselsopholdet som muligt (Kristelig Dagblad 29. juni 2001).

Efterfølgeren blev Anders Troldborg, kaldet en af »Madsens drenge« efter departementschef Niels Madsen, som lige nåede at få sin daværende afdelingschef udnævnt til direktør for kriminalforsorgen. Et signal om, at ju-

8. Direktoratet for Kriminalforsorgen 1. kontor journalsag 57-2-79, Rigsarkivet. Se også Fransen 2010 s. 104-108.

9. Direktoratet for Kriminalforsorgen 1. kontor journalsag 57-1-1980, Rigsarkivet. 
stitsministeriet stadig ønskede at sidde tæt på direktoratet. Troldborg var en dygtig administrator, der i 1993 blevet hentet til forsvarsministeriet som departementschef. Undvigelser, kriminalitet begået under udgang og under prøveløsladelser skabte krav om stramninger. Så godt som alle direktører for direktoratet har oplevet, at deres afgang er blevet krævet både fra folketingets talerstol og/eller i aviser og tidsskrifter. Det gjaldt også for Troldborg, men i endnu større udstrækning for hans efterfølger Christian Trønning (1993-1998), som ligeledes kom fra en stilling som afdelingschef i justitsministeriet. De repræsenterede cheftyper, der ikke var så dybt inde i selve det fængselsideologiske arbejde, og direktørposten syntes mere at blive en administrativ stilling, hvor selve spørgsmålet om engagementet i de strafferetslige spørgsmål var uddelegeret til andre. Både under Troldborg og Trønning blev der præsenteret flere store betænkninger, som direkte sigtede på at forbedre de indsattes vilkår (Betænkning 1058, 1986, Betænkning 1099, 1987 og Betænkning 1181, 1989-90). Alle arbejder havde haft direktoratets opstigende stjerne William Rentzmann med ved bordet. Da Trønning blev direktør, var det arbejdet med at realisere Arbejde- Undervisning- og Fritidsreformen, der var i fokus. Der skal ikke her nærmere redegøres for AUF-reformen, men det skal dog nævnes, at tiden i fængslet ikke længere blev set som en adskilt størrelse, men som et hele. Udefra betragtet blev den allerstørste gevinst i fangehåndteringen - fangernes selvforvaltning. Der skulle skabes en mere ansvarlig hverdag for den indsatte, som selv skulle tage ansvar for at møde på arbejde eller undervisning og selv lave sin mad evt. sammen med andre i madgrupper. Den indsatte skulle selv sørge for sit tøj, rengøring af sin celle samt samarbejde med de øvrige indsatte om at holde orden og rengøring på et acceptabelt niveau på fællesarealer. Gevinsten har først og fremmest været, at det giver fangerne en mulighed for at foretage sig noget fornuftigt og opretholde en struktur også i fritiden.

Et andet initiativ af blivende værdi var arbejdet med Kriminalforsorgens Principprogram, som blev sat på print i 1993. Foruden pædagogiske redegørelser for krav, formål og hovedopgaver for kriminalforsorgen blev der opstillet principper for arbejdet herunder:

- Normalisering. Kriminalforsorgen skal ved tilrettelæggelsen af dagligdagen, og hver gang der træffes konkrete afgørelser, have forholdene i det almindelige samfund for øje.

- Åbenhed. Kriminalforsorgen skal tilrettelægge virksomheden således, at de dømte får gode muligheder for at knytte og vedligeholde forbindelsen til de pårørende og det almindelige samfundsliv.

- Ansvarlighed. Kriminalforsorgens virksomhed skal tilrettelægges således, at de dømte får mulighed for at udvikle ansvarlighed, selvrespekt og selvtillid samt motiveres til at være aktive i bestræbelserne på at muliggøre et liv uden kriminalitet. 
- Sikkerhed. Kriminalforsorgen skal fuldbyrde de idømte straffe således, at der tages hensyn til beskyttelsen af den almindelige borger mod kriminalitet og til beskyttelsen af den indsatte mod overgreb og skadelig påvirkning fra andre.

- Mindst mulig indgriben. Kriminalforsorgen skal vælge den mindst indgribende foranstaltning, som er egnet til at løse en bestemt opgave. (Kriminalforsorgens Principprogram, s. 10-16).

Intentionen var, at principprogrammet skulle gennemsyre hele kriminalforsorgen, og alle medarbejdere skulle arbejde og handle ud fra disse. Arbejdet var blevet drevet frem af William Rentzmann, som nu var avanceret til vicedirektør. Der var roser og klap på skulderen fra mange sider herunder fra Nordskov Nielsen, der allerede 1992 skrev, at programmet på det overordnede niveau gav svaret på de problemer, som han havde påpeget ved fængselsvæsenet i slutningen af 1960'erne. Han bemærkede, at arbejdet hørte til de mest positive faglige oplevelser, han havde haft i mange år (Nordskov Nielsen 1992, s. 8-9). Principprogrammet havde hentet stor inspiration fra Ole Ingstrup, chef for det progressive føderale canadiske fængselsvæsen 1988-1992 og 1996-2000, og deres »Mission Statement (Ingstrup 1992, s. 6-7). Ingstrup havde sin rod i det danske fængselsvæsen, og var ligeledes en af Nordskov »disciple« og selv sparringspartner for mange danske fængselsfolk, ikke mindst William Rentzmann.

I Trønnings regeringstid blev kriminalforsorgen ramt af flere møgsager (bandekonflikten flyttede for alvor ind i fængslerne, spektakulære fangeflugter og igen kritik af økonomistyringen). Direktørens afgang kom i kølvandet på eksterne undersøgelser, som viste en uprofessionel økonomistyring (Fransen 2010, s. 135).

Med inspiration fra New Public Management blev den offentlige sektor i Danmark fra slut-90'erne præget et stigende krav om effektivisering og en større grad af rammestyring. Et af styringsredskaberne blev de såkaldte flerårsaftaler, som fra finansministeriet bredte sig til ministerier, styrelser og efterhånden også institutioner. Denne rammestyring stækkede direktørens råderum, ikke fordi de traditionelle bevillinger via finansloven nødvendigvis blev mindre, men fordi fokus og arbejdsbyrden ved at realisere de opstillede resultatkravmål kom i centrum. I 1998 indgik en kreds af forligspartier den første flerårsaftale om Kriminalforsorgen for perioden 1999-2003. Kriminalforsorgen fik i alt tilført ca. 1,4 mia. kr. til at gennemføre en række initiativer. Til gengæld skulle der effektivisere (Beretning 2003, s. 5). Initiativer skulle især rettes mod bekæmpelse af bandemedlemmer og narkomisbrug. Reelt blev det også indgreb imod de normaliseringstiltag, der ellers blev set som selve den danske kriminalforsorgs hæderstegn. Dette paradoks havde udviklet sig siden 1980'erne, men var blevet forstærket i 1990'erne og fortsatte i det nye årtusinde. Ikke desto mindre blev det William Rentzmann, en fortaler for normaliseringstankegangen og den humane fangebehandling, der fra 1998 
og helt frem til slutningen af 2012 kom til at beklæde posten som direktør for kriminalforsorgen.

Hans første store opgave var arbejdet med straffuldbyrdelsesloven, hvor han som medlem af Straffelovrådet og med direktoratet som sekretariat arbejdede intenst med de sidste detaljer. Loven blev vedtaget i 2000, efter mere end 15 års forberedelse (Rentzmann, Esdorf og Mikkelsen 2003 s. 23). Som den fremtrædende fængselsinspektør og senere direktør for kriminalforsorgen i Grønland, Hans Jørgen Engbo bemærkede i 2010, så revolutionerede loven ikke straffuldbyrdelsen i Danmark. I helt overvejende grad kodificerede loven gældende ret (Engbo 2010, s. 197). Loven kan ses som endnu et udtryk for, at der fra politisk hold var et ønske om en større indflydelse på straffuldbyrdelsen med denne selvstændige lov. Rentzmann mærkede også hurtigt politikernes øgede bevågenhed, hvilket bevirkede en voldsom vækst i antallet af spørgsmål stillet af retsudvalget og de enkelte folketingsmedlemmer. Direktoratet skulle besvare spørgsmål om f.eks. konkrete indsatte, arbejdsmiljø, behandlingstiltag og straffuldbyrdelsesregler. De svar, som Rentzmann skulle stå på mål for som direktør, var i stadig sigende grad om skærpede forhold for fangerne. Bølgen fra slutningen af 1960'erne og igennem 1970'erne med normaliseringstankegangen og humane krav, om hvordan kriminalforsorgen skulle håndtere sine fanger/klienter, havde lagt sig. At det politiske pres havde direkte indflydelse på fangernes afsoningsforhold ses klart, når der blev indført reguleringer i brugen af håndvægte (undgå »aggressive muskelbundter«), tvungne urinprøver (afsløre misbrug efter udgang), begrænse retten til internet og styrket indsats mod mobiltelefoner i fængsler. Tiltagene må ses som en delvis tilbagevenden til afstraffelsesprincipper i fængslerne. Rentzmann var som loyal embedsmand med til at implementere disse skærpelser, men han forsatte utrætteligt med at tale om vigtigheden af resocialisering i fængslerne og normaliserings/rettighedsprincipperne. Han har i utallige artikler, kronikker og interviews redegjort for sine grundsynspunkter om at behandle fangerne ordentligt, hvilket han pointerede er noget andet end at være blødsøden (Kristeligt Dagblad 23. august 2014).

I sin bog Sku' det være en anden gang fabulerer han over sit liv, men giver også særdeles vægtige indspark til debatten om kriminalforsorgens rolle. Heri kan man også se, at han gradbøjer begrebet normalisering i lyset af de udfordringer, som samfundsudviklingen stiller og ikke mindst det problematiske hensyn til befolkningens (den lovlydige) retsfølelse. Bandeproblematikken i samfundet og de domfældte bandemedlemmer skabte problemer i fængslerne, og modsvaret blev særlige afdelinger for bandemedlemmer, da de udgjorde en plage for andre indsatte og ansatte. Profilen for fangerne i de danske fængsler havde da også ændret sig markant, siden Rentzmann i 1970 påbegyndte sin karriere. Dengang blev $85 \%$ dømt for berigelseskriminalitet og $12 \%$ for vold, omkring 2010 udgjorde de voldsdømte $35 \%$, og andelen af dømte for berigelseskriminalitet var faldet til 25 \% (Rentzmann 2011, s. 79). 
Relationsarbejdet i fængslerne var ikke blevet opgivet, for mens modløsheden bredte sig i fængslerne i 1970'erne med opgivelsen af behandlingsfilosofien - kendt i Vesteuropa under slagordet What Works - Nothing Works, har bl.a. Willian Rentzmann snusfornuftigt tilsluttet sig det realistiske synspunkt, at Something Works Sometimes for Somebody, et slogan udgået fra det canadiske fængselsvæsen (Rentzmann 1995). Det resulterede i et omfattende »katalog" med flere end 50 forskellige behandlingsprogrammer til de indsatte ofte udbudt af behandlere uden for kriminalforsorgens egne rækker. Der var behandlingsprogrammer angående narkotikamisbrug, alkoholmisbrug, voldsforebyggelse, sexologisk behandling, kognitive færdigheder m.fl. Målet var stadig at resocialisere fangerne (Fransen 2017B, s. 219).

\section{Stadigt stigende fokus på den fysiske sikkerhed i fængslerne, samt øget polarisering i samfundet. Direktørerne Johan Reimann 2013-2017, Thorkild Fogde 2017-2020 og Ina Eliasen 2020-}

Da Johan Reimann tiltrådte som direktør i 2013 valgte justitsministeriet en person, som ikke var opfostret i kriminalforsorgens system. Med en alder på 59 år og en åremålsansættelse på 4 år var intentionerne at forsætte den linje, som allerede var afstukket. En linje forankret i de mål, der blev opstillet i flerårsaftaler og direktørkontrakter. Som det hed i den socialdemokratiske justitsminister Morten Bødskovs pressemeddelelse ved udnævnelsen, skulle Reimann gå forrest for at sikre en mere omkostningseffektiv og moderne kriminalforsorg med fokus på både sikkerhed og resocialisering (Justitsministeriets pressemeddelelse 17. december 2012). Med valget af Reimann fik kriminalforsorgen endnu en lærd personlighed, som dog ikke havde kriminalforsorgen så meget under huden som sin forgænger, men som til fingerspidserne forstod det politiske og administrative system. Karrieren havde selv for en topembedsmand budt på flere spektakulære sager, som havde bragt ham i offentlighedens søgelys. I sin tid som kontorchef $\mathrm{i}$ justitsministeriet var han dybt involveret $\mathrm{i}$ Tamil-sagen, som førte til, at justitsminister Erik Ninn-Hansen blev idømt fire måneders betinget fængsel for brud på ministeransvarlighedsloven. Reimann slap med en næse, og han kunne forsætte sin karriere både i og uden for ministeriet. I 2006 blev han udnævnt til politidirektør for Nordsjællands Politi, og i 2009 blev han politidirektør for Københavns Politi (Politiken 19. maj 2009). I dette embede gav især Københavns politis håndtering af demonstrationer mod Kinas politik i Tibet under det kinesiske statsbesøg i Danmark i 2012 anledning til hård kritik og kommissionsundersøgelse. Mens kommissionen rullede, havde Reimann skiftet til stillingen som direktør for kriminalforsorgen. Tilbage i 1994 havde han sammen med William Rentzmann udgivet bogen Samfundstjeneste og ungdomskontrakter, og i sin tid som politidirektør for Nordsjællands Politi sad han som formand for Kommissionen vedrørende 
ungdomskriminalitet. Kommissionen bestod af en bred vifte af eksperter inden- og uden for straffelovens ressort, men ikke desto mindre blev arbejdet færdiggjort på mindre end to år. Fra kriminalforsorgen deltog kontorchef Ina Eliasen. Reimann havde med andre ord også en solid ballast til at bestride posten som direktør for kriminalforsorgen. Han talte for videst mulig brug af samfundstjeneste og fodlænker, frem for fængsel. De indsatte skulle ses som ganske almindelige mennesker, der har samme ambition som han selv om et godt og redeligt liv. Kriminelle havde haft en skæv tilgang til livet og grebet galt i posen. Og eftersom den tanke var fordomsfri, anførte han også, at de fleste kunne påvirkes til ikke på ny at begå kriminalitet (Politiken 18. marts 2013).

Reimann markerede sig dog ikke meget i offentligheden vedrørende principielle spørgsmål om fangebehandling - han fungerede igen som den loyale embedsmand, der ikke luftede særstandpunkter. I forhold til at begrænse antallet af fængslede arbejdede han som medlem af Straffelovrådet med at samfundstjenesteordningen. Den ordning, han 10 år tidlige varmt havde anbefalet, blev nu blev yderligere udvidet (Betænkning 1545, 2014).

Flersårsaftale for kriminalforsorgen 2013-2016 - lagde øget vægt på sikkerheden og forøgede antallet af fængselspladser, men lagde samtidig op til en øget brug af alternativer til frihedsstraf og tidligere udslusning for særlige grupper af fanger. Der var også fokus på nytænkning af resocialiserende indsatser. Uddannelses- og beskæftigelsesindsatsen skulle styrkes, og samarbejdet mellem kriminalforsorgen og kommunerne skulle forbedres (Flerårsaftale 2013-2016). Ina Eliasen, som da aftalen blev indgået var kontorchef i direktoratet, bedømte i 2016 denne flerårsaftale og dens resultater positivt. Der havde været råderum til forbedringer og effektiviseringer af kriminalforsorgens kerneydelser - forholdet til klienterne/fangerne - ikke blot sikkerhedsmæssige stramninger (Eliasen, 2016).

I Reimanns periode mistede kriminalforsorgen endeligt sin position som et ministerumiddelbart direktorat. Direktøren for kriminalforsorgen stod frem til 2014 umiddelbart under justitsministeren i spørgsmålet om fuldbyrdelsen af de straffe, som reguleres i straffuldbyrdelsesloven. (Hvidbog, s. 18). Departementet kunne fra 2014 udstede generelle og konkrete tjenestebefalinger til kriminalforsorgen, herunder indkalde sager til afgørelse fra det pågældende direktorat. Det var reelt en tilpasning til det herskende magtforhold mellem justitsministeriet og kriminalforsorgen, som nu også formelt er en styrelse under ministeriet. Hvad tidligere direktører indædt havde kæmpet for at bevare blev nu strøget uden voldsomme protester fra direktoratet. Direktoratet var mere optaget af implementeringen af den interne struktur med oprettelse af fire geografiske områdeledelser. Dermed var den tidligere magtfulde stilling som fængselsinspektør reduceret til institutionschef og både formelt og reelt underlagt områdeledelsen. Set fra fangernes side skulle det sikre en bedre retssikkerhed og en mere ensartet behandling.

Da Reimann lod sig pensionere i 2017, valgte justitsministeriet igen at hente den siddende direktør for Københavns politi ind som chef. Den 51 
årige Thorkild Fogde kom som sin forgænger fra en stilling som politidirektør ved Københavns Politi. Tidligere havde han været politidirektør for Nordsjællands Politi, chef for politiområdet i Rigspolitiet. Før politikarrieren havde han haft afstikkere til statsministeriet og Bruxelles, men var frem for alt skolet i justitsministeriets hierarki, blandt andet som afdelingschef. De politiske forventninger til direktøren var meget lig de forventninger, som blev ventileret ved Reimanns tiltrædelse. Den konservative justitsminister fortsatte i samme sikkerhedsspor - og gav det yderligere en accent. I forbindelse med udnævnelsen udtalte justitsminister Søren Pape Poulsen bl.a., at Fogde var "den helt rigtige mand til at håndtere de sikkerhedsmæssige udfordringer, som desværre er blevet en realitet i landets fængsler (Justitsministeriets pressemeddelelse, 21. februar 2017). Modsat justitsministeren glemte Thorkild Fogde dog ikke fangernes resocialisering i pressemeddelelsen. Han anførte, at fasthed og konsekvens i straffuldbyrdelsen går hånd i hånd med en velfungerende indsats for at hjælpe dømte ud af kriminalitet.

Den flerårsaftale, som efterfølgende blev landet for perioden 2018-2021 - med VLAK- regeringen (Venstre, Liberal Alliance og Det Konservative Folkeparti) samt Socialdemokratiet og Dansk Folkeparti, havde en hidtil uhørt hårdhed i tonen over for de indsatte (Flerårsaftale 2018-2021). Det flugtede med justitsminister Søren Pape Poulsens udtalelse om, at det skulle være hårdere at sidde i fængsel, og han varslede et opgør med, hvad han kaldte 70'er-mentaliteten i landets fængsler (Information 10. marts 2017). Det var et retorisk opgør og en krigserklæring til fængselsvæsenets dogme om, at det er selve frihedsstraffen, der er straf nok i sig selv. »Undskyldningen« for de yderligere stramninger over for de indsatte i fængslerne lød:

"De indsatte afsoner generelt længere domme, og banderne fylder mere i fængslerne. Desuden har øget brug af alternative afsoningsformer som f.eks. fodlænke og samfundstjeneste for de mindst alvorlige forbrydelser betydet, at de mindst belastede kriminelle ikke længere kommer i fængsel i samme grad. Det betyder, at kriminalforsorgens ansatte flere steder oplever en stigende forråelse, idet en del af de indsatte er blevet mere socialt og kriminelt belastede over tid« (Flerårsaftale 2018-2021).

Modforanstaltninger skulle være yderligere fysiske sikkerhedstiltag såsom avanceret teknisk sikkerhedsudstyr, mere kontrol af banderelaterede indsatte herunder øget sektionering (mindre afdelinger) samt etablering af et udvisningsfængsel i det tidligere lukkede mande- og kvindefængsel i Ringe. I udvisningsfængslet skulle der ikke tilbydes resocialisering. Der skulle også oprettes et rent kvindefængsel i det halvåbne fængsel i Jyderup. Det ligger uden for artiklens rammer at give en nærmere vurdering af disse særfængsler, men begge tiltag ligger milevidt fra tanken om, at livet i fængslerne i størst mulig omfang skulle afspejle livet i det omgivne samfund.

Flerårsaftalen fremkaldte mange reaktioner - herunder fra Hans Jørgen Engbo. Hans evaluering i 2020 af konsekvenserne af flerårskontrakten mundede ud i en sønderlemmende kritik. Resultatet var blevet en politisk bestemt 
forråelse af fængselsklimaet og skabt en atmosfære præget af fjendtlighed frem for konstruktive, dialogbaserede relationer mellem personalet og de indsatte (Berlingske 22. juli 2020). Der var med andre ord et polariseret landskab både i fængslerne og på det politiske områder, som Fogde havde stået overfor.

Politigerningen trak dog mere i Fogde. I 2020 blev han udnævnt til Rigspolitichef, og han fik få dage efter sin tiltrædelse bogstaveligt et folkeligt gennembrud. Han fik stjernestatus, da han myndigt og tillidsvækkende på TV optrådte skulder ved skulder med statsministeren, da Danmark i marts 2020 indførte tiltag, der skulle dæmme op for udbredelsen af COVID-19 smitten. (Eva Bøgelund, 2020). Siden bevirkede en udløber at COVID-19-pandemien den såkaldte minkskandale - at han kom ud i et politisk stormvejr, der kunne havde kostet ham stillingen.

Kriminalforsorgen stod i 2020 over for at skulle have sin tredje direktør inden for 7 år. En indikation på, at stillingen nu mere var en ren administrativ stilling - uden det helt store engagement i at udvikle fængselsvæsenet og fangebehandlingen? Eller var der tale om, at arbejdet som topembedsmand var blevet så hårdt, at man ikke holdt så længe som tidligere? Det sidste var Thorkild Fogdes vurdering, da han tiltrådte som Rigspolitichef - tiden med »bedstefarledere« var forbi, som han kontroversielt udtalte (Eva Bøgelund, 2020).

Justitsministeriets valg faldt igen på en person, der kom fra politiet. Alligevel var der flere forskelle end ligheder i den karrieremæssige baggrund. Nok kom Ina Eliasen fra en stilling som HR-chef ved politiet, men hun var dog primært rundet af sin karriere inden for kriminalforsorgen. Hun havde bl.a. været områdedirektør for Kriminalforsorgen i Hovedstaden, fungerende fængselsinspektør på Københavns Fængsler og kontorchef i Direktoratet for Kriminalforsorgen. Hun havde været rundt på så godt som alle kontorer i direktoratet og gennem 10 år været chef for straffuldbyrdelseskontoret. Her havde hun bl.a. været ansvarlig for udviklingen af kriminalforsorgens kerneopgaver herunder at sikre evidens for nye indsatser over for klienterne/fangerne samt evaluering af de eksisterende tilbud. På spørgsmålet, om der var personer, der havde motiveret hende til at arbejde inden for kriminalforsorgen, pegede hun på William [Rentzmann]. Han havde for hende og en lang række af hendes jævnaldrende været den store inspirator, og han havde med sine humane og rettighedsbasserede holdninger til kriminalforsorgens opgaver givet arbejdet mening (Eliasen 2016). En hel generation af fængselsfolk var stærkt påvirket af William Rentzmann - på samme måde, som Nordskov Nielsen påvirkede en hel generation af tidligere fængselsfolk.

Ina Eliasen udtalte i et interview kort efter sin tiltrædelse om de særligt hårde typer af fanger:

»Det, det typisk virker, er at trække i folk og skubbe til folk. Altså at kunne tage nogle rettigheder, men også give mulighed for at give nogle rettigheder. Der gør vi sådan set også med en bred pensel i Danmark: Man begynder i 
lukket fængsel, og hvis det går godt, så kommer man i åbent fængsel. På den måde arbejder vi med den her rettighed- og pligttilgang allerede ... ... Jeg kan godt tegne nogle principper op, men i sidste ende er det en politisk beslutning" (Berlingske 17. juli 2020).

Hun anførte videre, at belægningsprocenten i fængslerne er høj, og der mangler fængselsbetjente, hvilket betyder, at fangerne er mere låst inde. På spørgsmålet, om løsningen er flere fængsler eller eventuelt færre fanger, glider hun af og henviser til, at det er et politisk spørgsmål, så spørgsmålet skal rettes til politikerne.

Især to forhold er vigtige at holde sig for øje:

- Fangernes rettigheder synes således at kunne gradbøjes - og problemet er vel ikke så meget, at man som fange mister nogle goder, hvis man overtræder reglerne, men derimod hvis reglerne er skruet sammen således, at det næsten med garanti fører til overtrædelser - eller hvis særlige grupper fra starten er frataget deres rettigheder.

- Principperne synes at måtte vige i forhold til den politiske virkelighed.

Viljen til at sætte fokus på de medmenneskelige relationer til de mennesker, som falder ind under strafsanktionerne i straffuldbyrdelsesloven, er dog til stede. Ina Eliasen pointerede nemlig i interviewet fra 2020, at på trods af mangel på mandskab og vægten på sikkerhedsopgaver, finder der stadig undervisning samt arbejde med misbrugsbehandling m.m. sted i fængslerne, men systemet er presset. På ledelsesniveau synes arven fra Nordskov Nielsen og William Rentzmann at leve videre. Om det er tilstrækkeligt til at kunne fungere som et bolværk for kriminalforsorg, vil tiden vise. William Rentzmann udtrykte tilbage i 2011 sin bekymring således:

»Nye sanktioner, længere straffe, hårdere afsoningsvilkår etc. kommer til verden under hård politisk og mediemæssig pres, ofte uden de traditionelle tidskrævende forberedende overvejelser i ekspertudvalg og så videre. I det hele taget har tiltroen til eksperter vel aldrig været lavere, end den er for tiden ... Vis mig den politiker eller meningsdanner, der har ændret opfattelse på grund af en kriminologisk undersøgelse, og jeg skal aldrig sige det mere« (Rentzmann 2011, s. 93).

Hans Jørgen Engbo var i 2020 mere skarp i sin kritik. Han så gerne, at Ina Eliasen fik mandat til at rette op på den politiske skabte misere. En genopretning der skulle ske sammen med personalet og med inddragelse af fængselsfaglig forskning (Berlingske 22. juli 2020).

Der er imidlertid ikke tegn på, at Rentzmanns pessimistiske udsagn om, at eksperter på området ikke er i høj kurs, vil blive gjort til skamme i den nærmeste fremtid. Der appelleres politisk til befolkningens retsfølelse, og kravet er stramninger. Selvom Danmark er i en situationen, hvor kriminaliteten generelt er faldende i samfundet, så er andelen af kriminelle med anden etnisk baggrund end dansk overrepræsenteret i de danske fængsler. Det gør det politisk 
nemmere at skabe opbakning til hårdere og skærpede afsoningsforhold, når der spilles på frygten for denne minoritet (Etnicitet og statsborgerskab, 2019). I 2021 er det vanskeligt at arbejde i forlængelse af Nordskov Nielsens appel fra slutningen af 1960'erne:

"de største sociale problemer, er de små minoriteters problemer, så vil vi i fængselsvæsenet gerne tro på, at den lille og ofte upopulære minoritet, vi har forpligtelse overfor, rummer en udfordring, der fortjener at blive taget op til en ny og bedre prioritering «. ${ }^{10}$

\section{Afrunding}

De hidtidige direktører har alle haft en juridisk embedseksamen som fagligt fundament for deres virke, og alle har kunnet fremvise et imponerende cv. Typisk har de været rundet af arbejde i ministerier og lederstillinger inden for retssystemet. Direktørerne har haft forskellig gennemslagskraft - ikke overraskende har de længst siddende haft en særlig mulighed for at opnå indflydelse. Billedet er dog ikke entydigt. På trods af sin korte regeringstid havde Nordskov Nielsen en ekstraordinær gennemslagskraft, mens Hans Tetens godt nok er den hidtil længst siddende direktør, men fremstår stækket af både justitsministeriet og de på godt og ondt - temmelig enerådige fængselsinspektører. Der er imidlertid også mere strukturelle fænomener, som gør sig gældende, herunder forholdet mellem administration og politisk ledelse. Der har været en stigende politisk vilje til at overtage styringen af området - selv ned i detailspørgsmål. Siden 1980'erne har spørgsmålet om straffuldbyrdelse fået stadig stigende politisk opmærksomhed, og fra omkring årtusindeskiftet er især ekspertbegrebet kommet under pres.

Fussing var ikke bleg for at tage kampen op for at få gennemført sine visioner. Det samme må siges om både Nordskov Nielsen, Brydensholt og Rentzmann, som alle markerede sig med faglige indlæg herom både i den brede offentlighed såvel som over for det politiske system. Indlæg som ikke nødvendigvis lå i direkte forlængelse af justitsministeriets/ministerens dagsorden. Generelt synes det nu at høre til sjældenhederne, at topembedsmænd markerer sig på denne måde. Det forventes ikke, at styrelsesdirektører deltager aktivt i den faglige debat - det er ikke deres fagspecifikke kompetencer, der efterspørges, men ledelseskompetencer. Der kan argumenteres for, at det er et udslag af den generelle professionalisering inden for den offentlige sektor. Måske er der ikke længere brug for en direktør for kriminalforsorgen, der aktivt deltager i den faglige diskussion om fangebehandlingen - måske bør det overlades til andre inden for eller uden for organisationen?

10. Slutningen på Nordskov Nielsens tale den 7. august 1969 til medlemmerne af folketingsudvalgene angående narkotikamisbrug og lovgivning vedr. pornografi. Journalnummer 4.k. 998-6 i direktoratets arkiv, Rigsarkivet.. 
Ud fra en kollektiv betragtning har alle de hidtidige direktører været eksponenter for den type af embedsmænd, som har efterlevet Bo Smidt-udvalgets anbefaling til den gode embedsmand samlet under prædikaterne lovlighed, sandhed og partipolitisk neutralitet (Bo Smidt, s. 25-23). Dertil kom at udvalget stillede krav til, at den gode embedsmand tilpasser opgaver til de politiske krav. Så langt så godt. Loyaliteten bør dog ikke blive en spændetrøje, som begrænser faglige og kritiske input. AEndrede samfundsstrukturer vil altid kalde på nye initiativer, også når talen falder på straffuldbyrdelse. Direktøren for kriminalforsorgen synes i stadig videre udstrækning primært at skulle udføre en administrativ rolle og ikke nødvendigvis føre ordet, når det gælder de principielle overvejelser om straffuldbyrdelse. Set i dette perspektiv kan det ikke overraske, at direktøren i 2014 mistede sin departementale status også i spørgsmål vedrørende fuldbyrdelse af de strafferetlige følger for de dømte. Set fra departementet blev der gjort op med, hvad der kunne betragtes som en anormalitet og en i forvaltningsmæssig forstand nu ukurant størrelse.

Kontaktoplysninger

Peter Fransen: pf@sa.dk

\section{Litteratur m.m.}

Aude-Hansen, Carl: Dansk Udvalgsbetænkning om Fuldbyrdelse af Frihedsstraf m. v. s. 3555 i Nordisk Tidsskrift for Strafferet. 1947.

Aude-Hansen, Carl: Standard minimumsregler for behandling af Fanger s. 149-177, i Nordisk Tidsskrift for Kriminalvidenskab. 1959.

Beretning til statsrevisorerne om flerårsaftalen for Kriminalforsorgen i 1999-2003. 2003.

Betænkning nr. 1058, 1986 Arbejde, Undervisning og Fritid bind 1-3. 1986.

Betænkning nr. 1099, 1987: Straffelovrådets betænkning om strafferammer og prøveløsladelse.

Betænkning nr. 1181, 1989-90. Betænkning om en lov om fuldbyrdelse af straf mv., afgivet af en arbejdsgruppe nedsat af Straffelovrådet.

Betænkning nr. 1355, 1998: Straffelovrådets betænkning om en lov om fuldbyrdelse af straf m.v.

Betænkning nr. 1545. 2014 Straffelovrådets betænkning om samfundstjeneste mv.

Brydensholt, H.H.: Historier fra dengang i 1970'erne - i ungdomsoprørets kølvand s. 207-230 i Martina Henze (red.): Direktoratet for Kriminalforsorgen 1910-2010. 2010.

Brydensholt, H.H.: Hvordan kan straffesystemet forbedres? s 11-17 i Kriminalforsorgen nr. 1 1975. 1975.

Brøndsted, H.H.: De åbne fængslers historie s. 8-99 i Fængselshistorisk Selskab 2019. 2020.

Bøgelund, Eva: Dagen før Thorkild Fogde begyndte som rigspolitichef, ringede telefonen ... i DJØFBLADET 4. juni 2020.

Eliasen, Ina: Interview med Ina Eliasen udført af Peter Fransen den 18. maj 2016.

Engbo, Hans Jørgen: Fængselsfaglige udfordringer gennem 100 år - belyst gennem udviklingen i dansk fængselsret 1910-2010, s. 153-205 i Martina Henze (red.): Direktoratet for Kriminalforsorgen 1910-2010. 2010.

Etnicitet og statsborgerskab. Justitsministeriet Direktoratet for Kriminalforsorgen Koncernledelsessekretariatet. 2019.

Flerårsaftaler: www.kriminalforsorgen.dk/om-os/kriminalforsorgens-opgaver/fleraarsaftaler/. 
Foreløbig Betænkning, afgivet af det af Justitsministeriet nedsatte Udvalg til Behandling af Spørgsmaal vedrørende Fuldbyrdelse af Fængselsstraf m. v. 1946.

Fransen, Peter: Altid en noget urolig etat s. 37-152 i M. Henze (red.), Direktoratet for Kriminalforsorgen 1910-2010. 2010.

Fransen, Peter: Borgen med de mange ansigter: Statsfængslet i Nyborg 1913-2013. 2013.

Fransen, Peter: Livet i de røde barakker. Horserød 1917-2017. 2017. (B).

Fransen, Peter: The Rise of the Open Prisons and the Breakthrough of the Principle of Normalisation from the 1930s Until Today s. 81-102 i Peter Scharff Smith og Thomas Ugelvik: Scandinavian Penal History, Culture and Prison Practice. Embraced By the Welfare State? 2017. (A).

https://doi.org/10.1057/978-1-137-58529-5_4

Fransen, Peter: Top embedsmandens vanskelige balance mellem politiske krav og faglig ansvarlighed s. 6-21 i Fængselshistorisk Selskab 2014. 2015.

Fussing, Thorkil: Betænkning angaaende Bestemmelser om Frihedsstraf og med Frihedsberøvelse forbundne Sikkerhedssforanstaltninger. 1921.

Fussing, Thorkil: Forarbejder til den nye danske Straffelov. Løsladelse paa Prøve s. 62-71 i Nordisk Tidsskrift for Strafferet. 1924.

Grundtvig, Stener: Overbestyrelsen for Danmarks Fængselsvæsen s. 65-73 i Nordisk Tidsskrift for Fængselsvæsen og praktisk Strafferet. 1910.

Hvidbog. Reorganisering i Kriminalforsorgen. 2013.

Ilsø, Grethe: Juridisk eksamen for ustuderede s. 111-148 i Personalhistorisk Tidsskrift 1985:2. Ingstrup, Ole: Mål, strategier og værdier s. 6-7 i Nyt Fra Kriminalforsorgen 12/92. 1992.

Kampmann, Erik: Fængselsvæsenet i Danmark efter den nye Straffelov s. 103-125, 158-185 i Nordisk Tidsskrift for Strafferet. 1933. (A).

Kampmann, Erik: Hovedprincipperne i den nye danske Straffelov med særligt Henblik paa de forandringer i Straffuldbyrdelsen, som den medförer. Foredrag af Direktør for Fængselsvæsenet i Danmark ved de nordiske Fængselsmøder - sandsynligvis i 1933. Særtryk fra Statsfængslet i Nyborgs fagbibliotek. 1933. (B).

Kampmann, Erik: Thorkild Fussing og dansk Fængselsvæsen. Et Tilbageblik ved Direktør Fussings Død den 7. Oktober 1930, s. 1-14 i Nordisk Tidsskrift for Strafferet. 1931.

Keats-Rohan, Katharine K. S.: Progress or perversion? Current Issues in Prosopography: An Introduction. 2003.

Kriminalforsorgen Årsrapport. 2007.

Kriminalforsorgens Principprogram, udgivet af Direktoratet for Kriminalforsorgen 1998.

Kristiansen, Jo Rune Ugulen: Prosopografi og historie. 2005.

Nilsson, Ida Novin: Forandringer mod mindre frihedsstraf i Danmark 1967-1977. 2014.

Nordskov Nielsen, Lars: Principprogrammet giver svar s. 8-9 i Nyt Fra Kriminalforsorgen 12/92. 1992.

Nordskov Nielsen, Lars: Udviklingslinier og reformer i kriminalforsorgen s. 481-491 i Juristen. 1969.

Om principperne for fuldbyrdelse af frihedsstraf for forræderi og anden landsskadelig virksomhed. Betænkning afgivet udvalget af 18. oktober 1945, nedsat af Frit Danmark. 1945.

Possing, Birgitte: Ind i biografien. 2015.

Rentzmann, William: Noget virker på nogen - nogle gange s. 10-12 i Nyt fra Kriminalforsorgen nr. 5/95. 1995.

Rentzmann, William: »Sku'det være en anden gang«. 2011.

Rentzmann, William: Vellykkede relationer er altafgørende i fængsler s. 100-109 i Fængselshistorisk Selskab 2019. 2020.

Rentzmann, Willian Annette Esdorf og Jens Kruse Mikkelsen: Straffuldbyrdelsesloven med kommentarer. 2003.

Schmidt, Kristoffer: Biografi, akribi og lidt om helte og heltinder s. 571-593 i Historisk Tidsskrift. 2015.

Smidt, Bo m.fl.: Embedsmanden i det moderne folkestyre, 2015. 
Stone, Lawrence: Prosopography s. 46-79 i Daedalus. Journal of the American Academy of Arts and Sciences, vol. 100. 1971.

Tetens, Hans: Nogle hovedlinier i fængselsvæsenets udvikling s. 4-32 i Fængselsfaglige Meddelelser nr. 1. 1956.

Tetens, Hans: De fængselsmæssige foranstaltninger overfor landssvigerfangerne i Danmark s. 159-19, i Nordisk Tidsskrift for Strafferet. 1947.

\section{Aviser og pressemeddelelser}

Berlingske 17. juli 2020, Kriminalforsorgens nye direktør slår et slag for åbenhedskultur, som tidligere har været til at overse.

Berlingske 22. juli 2020, Fhv. fængselsinspektør: Politikerne står nu i kø for at hjælpe Kriminalforsorgen - men de har selv skabt problemet.

Information den 10. marts 2017, Søren Pape: „Vi er så bange for at komme til at være for hårde i det her samfund."

Kristeligt Dagblad 23. august 2014, William Rentzmann »Hvis man vil have folk til at opføre sig ordentligt, skal man også behandle dem ordentligt."

Kristelig Dagblad 29. juni 2001, Nekrolog over Frits Hellborn

Nationaltidende 2. marts 1924, Det er de Uskyldige der lider mest.

Politiken den 19. maj 2009. Tamil-sagen gav Reimann skrammer.

Politiken den 18. marts 2013. Sheriffen, der kan styre det hele, fylder rundt.

Pressemeddelelser fra Justitsministeriet:

Ny direktør for Kriminalforsorgen 17. december 2012 (www.justitsministeriet.dk/pressemeddelelse/ny-direktoer-for-kriminalforsorgen/.

Thorkild Fogde bliver ny direktør for kriminalforsorgen. 21. februar 2017 (www.justitsministeriet.dk/pressemeddelelse/thorkild-fogde-bliver-ny-direktoer-for-kriminalforsorgen/.

Ny direktør for kriminalforsorgen 20. maj 2020 (www.justitsministeriet.dk/pressemeddelelse/ny-direktoer-for-kriminalforsorgen-2/). 